\title{
Admissibility of Lis Pendens in International Commercial Arbitration: A Comparative Insight of Different Legal Systems
}

\author{
Ximei $\mathrm{Wu}^{1,2} \&$ Abid Hussain Shah jillani ${ }^{1,3}$ \\ ${ }^{1}$ School of Law, Zhengzhou University, China \\ ${ }^{2}$ School of Public Policy, University of Calgary, Canada \\ ${ }^{3}$ Bahauddin Zakariya University, Multan, Pakistan \\ Correspondence: Abid Hussain Shah jillani, School of Law, Zhengzhou University, Room 505, Unit 1, Building 5, \\ Yuhua Manyuan, Gaoxin District, Zhengzhou 450001, China. E-mail: Abidshahjillani@outlook.com; \\ dr_abidshah@gs.zzu.edu.cn
}

Received: July 30, 2020

Accepted: October 4, $2020 \quad$ Online Published: October 13, 2020

doi:10.5539/jpl.v13n4p134

URL: https://doi.org/10.5539/jpl.v13n4p134

\begin{abstract}
An attempt has been made to investigate the role of the doctrine of Lis Pendens in international commercial arbitration while making a comparison of civil and common law traditions. Arbitration is regarded to be less painful and an effective means for resolving any type of commercial disputes. Sources of the law to investigate Arbitration's regulation on a national, institutional, and international level. However, it is known that the lis pendens doctrine has been rarely codified; thus, scholarly writings and case laws were consulted by the research for determining its adoption and content. It is important to note that the lis pendens is initially regarded as a tool, which has been developed to manage the proceedings of parallel court on a domestic level. The study concludes while arguing that when it comes to civil law tradition, lis pendens is regarded as an independent doctrine in international commercial arbitration since it shares the same claim of being tried in various forums simultaneously. In contrast, lis alibi pendens in the jurisdiction of common law is not known as a doctrine, but it is viewed as one of many factors whole applying the forum non-convenience principle. Both civil and common law need identity between various parties and their claims to constitute lis pendens in two proceedings, and therefore, they have a conform and deep understanding of the concept.
\end{abstract}

Keywords: civil law tradition, commercial arbitration, common law tradition, international commerce court, lis pendens, UNCITRAL, lis pendens

\section{Introduction}

"Arbitration" is an English concept, whose legal lexicon's roots are formed by the Greek word "Diaitisia" and the Latin word "Arbitus."Arbitration was promoted between 330-90 BC by the Greek legal culture as the most valuable social justice instrument to settle all property law related matters(Lew et al., 2003). Arbitration's first interstate legal norm was created by mixing Roman diplomacy and Greek arbitration when the Roman Empire and Greeks came in contact. Antiquity law's well-documented history is the Roman Republic Law's sophistication, which gave way to the world's contemporary legal arrangements. The Roman law of property provided the distinction between the actual possession and the legal ownership of real property, "dominium proprietas," or property rights. The dependence of the Roman legal system was wholly on the rule of law. In the social "equity" or equality concept of Aristotle, the Greek legal philosophy is rooted deeply. Aristotle appropriately defines the saying of equity within arbitration's parlance. It says, "it is better to prefer arbitration from judicial determination; because the arbitrator takes equity into consideration, whereas the judge solely the law.

Furthermore, it is for this reason that an arbitrator appointed, that is, to apply equity." In the parties' legal principle to the arbitration, contemporary international arbitration is firmly rooted, which is submitting fully so that a dispute settled via arbitration in a third forum. To the enforcement and recognition of the award, the parties also agree. International arbitration's topic is complicated and vast. Arbitration has been confined into six broad categories by the legal scholars: 1) commercial arbitration, 2) ad hoc arbitration, 3) international arbitration, 4) non-commercial arbitration, 5) domestic arbitration, and 6) institutional arbitration. Within private international law, the doctrine of internal comity relates to the law principle of lex loci. To other states, legal systems, legally non-binding 
deference, is International comity as an international diplomacy matter(Born, 2014). The literature points out international arbitration's complications in proceedings under the doctrine of lis alibi pendens. These complications occurred when the first-time rule was violated because the forum clause was excluded in arbitration agreements. Under private international law, in international arbitration's matters, the Lis Alibi Pendens' doctrine rises when the implementation of jurisdiction over a case is refused by the court, which is pending in another jurisdiction(Merryman and Pérez-Perdomo, 2018).

For instance, Arbitration statistics 2016, 2017, and 2018 show how many organizations preferred arbitration to settle the dispute.

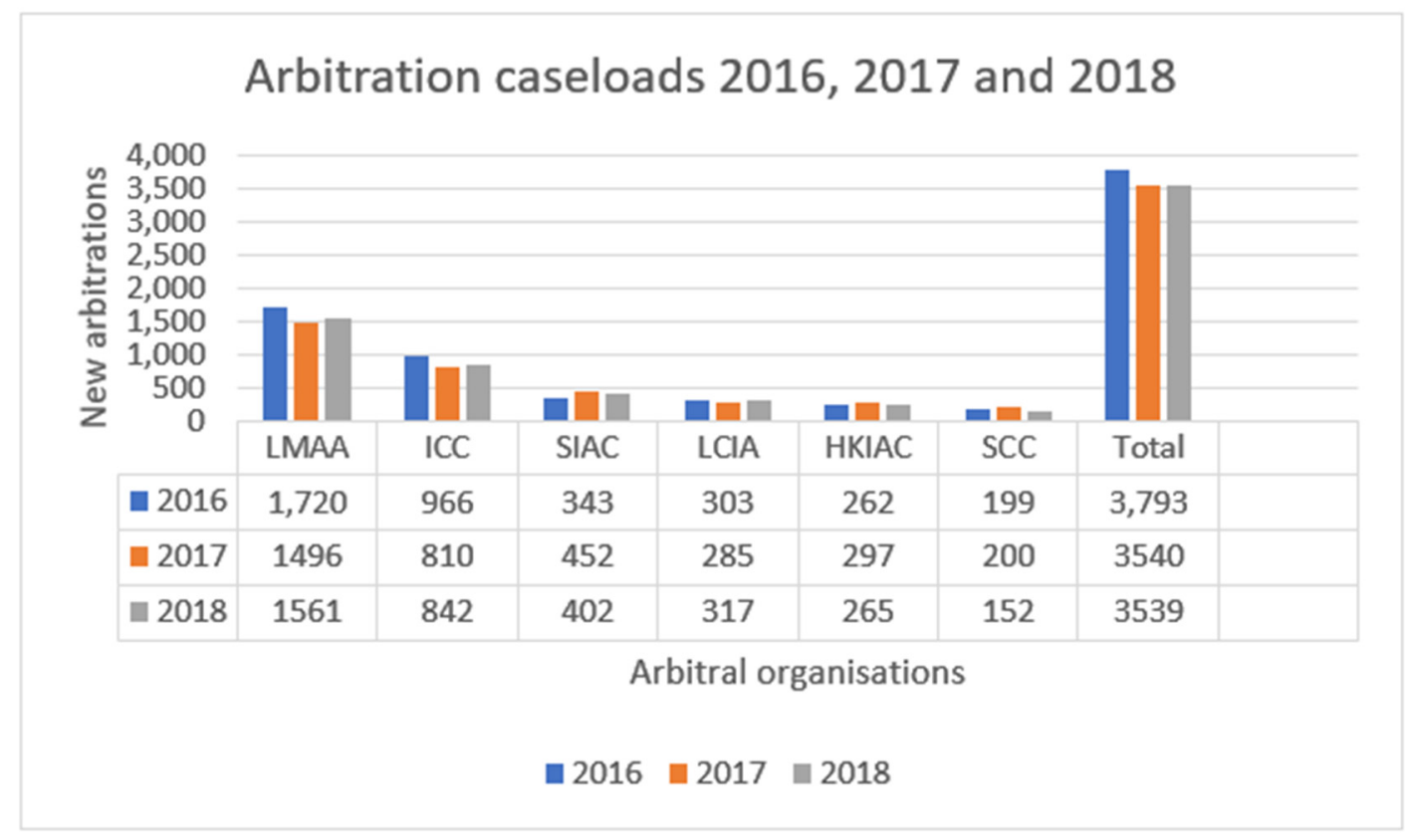

Figure 1. Arbitration caseloads 2016, 2017 and 2018 (Clanchy, 2018)

Lib Alibi Pendens doctrine is not applicable if the case's facts differ. The study would address the following questions: What are Arbitration's concept and its legal sanity in international law? How do the procedures in the common law and civil law traditions influence Arbitration? How does the doctrine of Lis Pendens play its role in international commercial arbitration? Explain the growing phenomena of Lis Pendens and challenges to international commercial Arbitration due to it? What is the possible solution to these challenges? The study would address the following aims and objectives: Investigate the parallel proceedings' problem and the adoption of Lis Pendens in the common and civil law, respectively, to assess when parallel proceedings accurately take place in international community arbitration. To some extent, this study is twofold; it would embark upon presenting the parallel proceedings and lis pendens' issue through overall perspective while keeping in view a party-oriented approach.

\section{Literature Review}

A plethora of literature has been produced over the Admissibility of Lis Pendens in Commercial Arbitration. Such material would help the researcher to conduct this study. There has been a question for arbitral tribunals and courts in terms of handling a case whether the matter is already in another forum or not. It can be called a tricky one. According to Gerhard, it plays an essential role in creating controversy in international arbitration under lis pendens doctrine.

Moreover, they argued that there could be a problem concerning "forum shopping" in international business, which has also led to adjudication's complication at the same time in various jurisdictions. The same notion was advocated by Mary Keyes while arguing that international arbitration's practice is seeking solutions for mitigating lis pendens' problems for parallel proceedings. It was aimed by the answer to investigate parallel proceedings before 1 or 2 proceedings and arbitral tribunals under lis pendens doctrine. It has been suggested by Joost and Salles the literature that within national jurisdiction, lis pendens doctrine evolved due to the reason that two adjudicatory forums have equal competence in the same matter. Anyhow, it was argued by the Christian that there 
could be seen in this scenario when there is a domestic adjudicatory forum, while there is the competence of the international court in terms of adjudicating the issue/matter as well. Under lis Pendens, such complexity is identified as a significant key challenge. According to August, it is clarified by ICCA that an arbitral tribunal or any court can have competence related to the jurisdiction. However, under lis pendens, such a situation plays an essential role in creating the situation in which a court's jurisdiction is excluded if any evidence is found concerning the arbitration clause's exclusivity over litigation.

\subsection{Significance of the Study}

In this study, an attempt has been made to compare two completely different approaches to lis pendens taken by the civil and common law. This comparison can be called quite interesting as both traditions have strongly influenced international arbitration. In connection to this, it is argued that the comparison will not fixate to one or few jurisdictions form civil and common law tradition, and it would also help illustrate the tradition they belong to. To put it differently, the study would deal with two legal practices and shed light on two or more jurisdictions. In the beginning, a general point of view will be taken concerning "common law tradition" and the "civil law tradition" but would be illustrated while using examples of many countries. Furthermore, an attempt would be made in this article to explain and investigate the internal difference between these two legal traditions.

Many studies have adopted a descriptive way of presenting problems, which later helps explain a solution to these problems. However, the current research has embraced a comparative method for analyzing a problem, which would help address the questions and analyze international arbitration at the national, institutional, and international levels. A plethora of literature has been produced over international arbitration and international proceedings. Such material would help the researcher to conduct this study.

\subsection{Some Fundamental Features of Arbitration}

Arbitration involves "two or more parties, faced with a dispute that they cannot resolve for themselves, agreeing that one or more private individuals will resolve it for them through Arbitration; and if the Arbitration runs it full course. it will not be resolved by a negotiated settlement or by mediation or by some other form of compromise, but by a decision which is binding on the parties."(Garner, 2009)In other words, it is argued that Arbitration is a method through which a dispute settled between two parties, who enter into an agreement. It is solved by the arbitral tribunal with the help of a binding and final decision method, and the arbitral tribune consists of one or more than one arbitrator(Garner, 2009). While keeping in view such a brief description, it is easy to identify some of Arbitration's fundamental features. First, it is essential to note that Arbitration plays its role as an alternative in formal court proceedings.

With the agreement of parties on Arbitration, the national court's jurisdiction is also excluded by them. Second, it is regarded as a private mechanism for dispute resolution since the hearing is non-governmental. It is either appointed either by an arbitration institute or the parties. Third, the tribunal decision would be the binding and final determination of the parties' obligations and rights to each other. For the parties, Arbitration's particular feature is known as the parties' freedom to control the proceedings via an agreement, as per widely recognized and the most significant party autonomy's principle. It is not revealed by Arbitration's definition of whether or not Arbitration is characterized international. With the characterization of arbitration as international, it can easily distinguish from national or purely domestic arbitration(Rush, 1994). Three different approaches have been adapted to how scholars perceive internationality's concept. The basis of the first approach is on the dispute's nature, and the Arbitration is regarded to be international; the contract possesses a transnational element, or if parties refer a dispute to the International Chamber of Commerce (ICC).

On the other hand, the second approach is solely based upon the parties' nationality. If a party's nationality is different from where its business is located in a different jurisdiction, arbitration is supposed to be international rather than national. As far as the third approach is concerned, it can be called the mixture of the previous two approaches and can also be called an adopted(George, 2017). Arbitration does not exist; however, arbitration depends ultimately upon being allowed to exist by national law. In addition to this, Arbitration is considered consensual, which means that it is essential for parties to agree for arbitration unless they have done it. For Arbitration, there is no legal ground to take place between parties. It has been contended that "for the arbitration agreement, and a final following arbitral award, to have legal status, it must be recognized by national and international law" (Blackaby et al., 2009). There is a regulation of Arbitration in international treaties, conventions, legislation, and institutional arbitration rules. By powerful trading nations, international conventions and treaties have entered into for facilitating international investment and trade.

Without any doubt, one of the most influential and popular international instruments is "The Convention on the Recognition and Enforcement of Foreign Arbitral Awards (7 June 1959. New York City, U.S.A.)," also known as 
the "New York Arbitration Convention" or the "New York Convention, "it is known as the principal instrument in international Arbitration. According to Zweigert, "the New York Convention applies to the recognition and enforcement of foreign arbitral awards and the referral by a court to Arbitration. The Convention imposes a duty on the national courts in the signatory States to guarantee the recognition and enforcement of foreign arbitral awards unless any of the few listed exceptions is applicable."(Rush, 1994) To create such legal standards to recognize and enforce foreign awards, a great help has been extended by the Convention in terms of facilitating Arbitration's usage in the international world. Despite its shortness and brevity, the Convention in international Arbitration has played a significant role, as it is argued that the "most effective instance of international legislation in the entire history of commercial law." (Fouchard and Goldman, 1999).

\subsection{Principle of Lis Pendens}

A global survey of more than 900 financial institutions that deal with finance, international trade, and commerce was conducted by the "Queen Mary University UK School of International Arbitration and International Arbitration Law Firm White \& Case" in 2018. The title of the survey was "The Evolution of International Arbitration." The survey revealed that arbitration was preferred by $97 \%$ of respondents (Fouchard and Goldman, 1999). Over international arbitration, litigation is preferred by only $3 \%$ of the participants. This result got down to $2 \%$ in 2015's similar survey results. The above findings deduce that to resolve cross-border clashes concerning commercial and civil cases, a worldwide desire for arbitration is increasing compared to litigation. The top ten centres of international arbitration are Singapore, Geneva, and London. It is not an unusual practice for obstinate parties to commence parallel arbitration proceedings in multiple jurisdictions(Born, 2014). To go, forum-shopping is the most reticent reason, but this is not the only reason the arbitration clause does not limit the forum's choice. If such a situation occurs in the arbitration proceedings, then the doctrine of lis pendens becomes paramount(Born, 2014). To avoid unnecessary costs and conflicting judgments, the doctrine of lis pendens allows for choosing the most appropriate forum. From jurisdiction to jurisdiction, the conflict of forum differs. If a conflict of the forum is not mitigated in arbitration proceedings running parallel in multiple jurisdictions, the risk of conflicting outcomes cannot reconcile. For this reason, the doctrine of lis pendens has been included by major arbitration centres in their domestic legislation so that the risk of conflicting outcomes can lessen because of the conflict of the forum.

For instance, in all the cases registered in 2013, the choice of law provision was included by parties in the contract, which led to the arousal of disputes. There no reliable and effective law preference of jurisdiction. However, English law was regarded to be the most popular governing law with $15.64 \%$ of clauses in the contracts of these parties as mentioned in the figure.

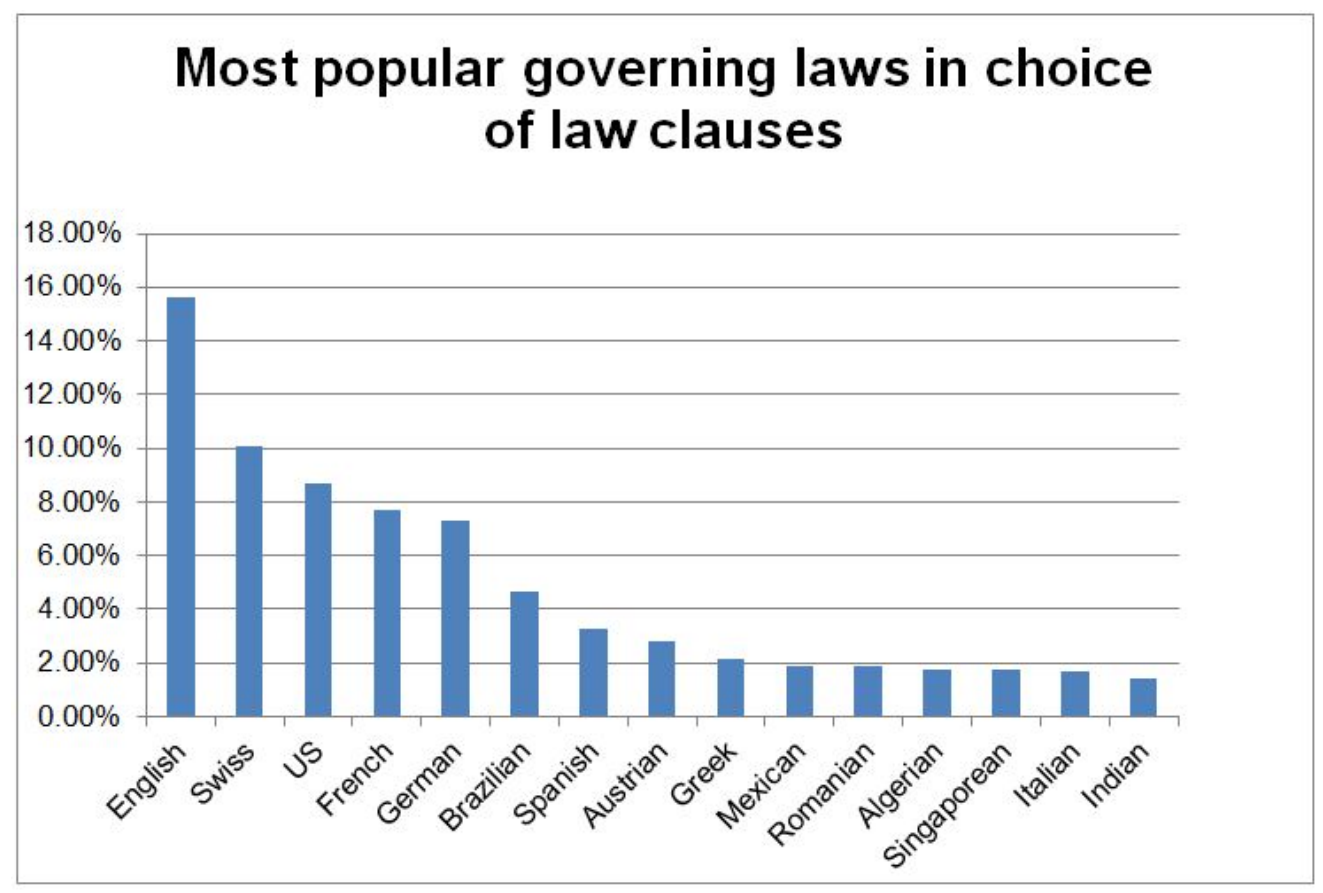

Figure 2. Most popular governing laws in choice of law clauses (The ICC, 2013) 
If the arbitration is based on international comity's principle in multiple jurisdictions, it might increase the conflict's complexity of a forum. The Swiss Federal Supreme Court ruled in the 2001 case of Fomento de Construcciones y Contratas S.A. v. Colon Container Terminal S.A that "the principle of lis pendens is well established in the civil procedure rules of most countries, [also] applies in arbitration proceedings governed by the Swiss Arbitration Act"(Redfern and Hunter, 2004). The doctrine of lis pendens in their arbitration's forum laws is recognized by Jurisdictions such as the City of Singapore and London. 1958 New York Convention for Arbitration also gets force from the doctrine of lis pendens. New York Convention 1958 is also referred to as UNCITRAL, United Nations Commission On International Trade Law Convention on the Recognition and Enforcement of Foreign Arbitral Awards. Proceedings of the court must stay under the doctrine of lis pendens if jurisdictional conflicts exist between an arbitration tribunal and court (Lewis, 2016). The court is allowed by the lis pendens doctrine to stay its proceedings in the arbitration tribunal's favour. Under the lex fori's principle is the only way to keep up the proceedings. The court's proceedings will take precedence if lex foxi applies and if the agreement is void and null under arbitration(Blackaby et al., 2009).

A vital role is played by lis pendens in both traditions related to parallel proceedings, but different functions have been given by it within each tradition to prevent parallel proceedings. The matter is complicated because there cannot be a universal definition of lis pendens; there are significantly fewer standards that have been universally adopted for its application. In this study, an attempt would be made by identifying parallel proceedings' issues in international arbitration. For instance, the triple identity test is conducted in civil law tradition, whereas Lis pendens and the first-in-time rule exist in the common law tradition

1) Lis pendens is regarded as a part of the forum inconvenient doctrine

2) Lis pendens is known as a separate doctrine

3) Requirements relating to identity.

\subsection{The Characteristics of International Commercial Arbitration}

In these industries of all renowned arbitration benefits of confidentiality, neutrality, speed, enforceability, flexibility, expertise, cost-effectiveness, efficiency, and finality, international arbitration offers businesses. Flexibility and neutrality are particularly essential in the international context(Hobér, 2011).

\subsubsection{Neutrality}

There is no need for any party to allow "home court" advantage to one another by choosing international commercial arbitration as for disputes' resolution, there is no need to resort to a domestic court of any country. Instead of that, impartial arbitrators solve the disputes free of any government (Heuman, 2003). Of many nationalities, international commercial arbitrators are available, and they all oblige as neutrals. In selecting arbitrators, parties are involved regularly, but to impartiality, all arbitrators nominated by the party are sworn. In US labour arbitration, the party advocate arbitrators are permitted sometimes. They are not known to commercial arbitration and whether impartiality can be maintained by an arbitrator (party-nominated) or not is an ongoing debate, but impartiality is a reality, expectation, and rule.

\subsubsection{Flexibility}

In international matters, arbitration's flexibility has significant importance because there may be inconsistency in dispute solving procedures that parties from various nations are used to, even contradictory Pre-Hearing "Discovery." For example, US lawyers have used and expected broad discovery, with the production of comprehensive pre-hearing documents, interrogatories, depositions, and admission requests. In international commercial arbitration, this is seldom allowed. It is provided by Article 21 of the 2014 International Arbitration Rules of the International Centre for Dispute Resolution ("ICDR") (the international division of the American Arbitration Association) explicitly provides that "depositions, interrogatories, and requests to admit as developed for use in U.S. court procedures generally are not appropriate procedures for obtaining information under these Rules." (Heuman, 2003)Under most international arbitral rules and ICDR, document requests are limited to "specific documents or documents classes" along with an explanation of their materiality and relevance (Heuman, 2003).

\subsubsection{Hearing}

Written presentations of argument and evidence are more inclined to be in a typical international arbitration hearing where a US lawyer might be expecting and used to oral presentations. In international commercial arbitration, commonplace includes extensive written reports given by expert witnesses and written statements provided by fact 
witnesses. Between the parties, factual witness statements are exchanged usually, and before the hearing, these statements are provided to the arbitrators(Born, 2014). Those written statements presage direct examination, and they may also replace it. In hearings of international commercial arbitration, the live testimony of witnesses is limited to cross-examination. From expert witnesses, written reports are always demanded. Their reports are exchanged between the parties, and before the hearing, these reports are submitted to the arbitrators. Most of the time, it will be recommended by the arbitrators to the opposing experts to consult with each other before hearing, and they will have to submit a list to arbitrators in which points will be mentioned upon which they agree and disagree. The experts can either question together or cross-examine on the issues upon which they disagree. "Witness conferencing" (testifying about the same problem and at the same time, examining witnesses) colloquially referred to as "hot tubing" is used with factual witnesses along with the expert witnesses. Witnesses are questioned directly by the international arbitrators, and when witness conferencing is used, they may even lead to questioning. Counsel will be allowed to examine by most international arbitrators with only occasional interjections, but some international arbitrators take over at will and early stage. Counselors may permit final oral argument at the hearing's end, but sometimes, post-hearing written submissions replace oral arguments.

\subsubsection{Award}

"Reasoned" awards are international commercial arbitration awards. There is nothing like AAA Commercial Rule 46(b) ("The arbitrator need not render a reasoned award unless the parties request such an award before the appointment of the arbitrator or the arbitrator determines that a reasoned award is appropriate.") in international commercial arbitration practice or rules.

\subsection{5 "Costs."}

"Costs" (a term which includes fees of attorneys in international parlance) "follow the event" in most of the national legal systems, which is generally the "loser pays" in winner's attorneys' fees and also in "winner's attorneys' fees." In a few national legal systems outside the US, the "American rule" is applied. The "loser pays" in most international commercial arbitrations (Lalive, 1987).

\subsection{Legal Framework}

To help states modernize and reform their laws on arbitral method, The UNCITRAL Model Law on International Commercial Arbitration is designed. All stages of the arbitral method are covered in the Model Law: arbitration agreement's formation, arbitral tribunal's alignment, and jurisdiction and court intervention's extent in identification and enforcement of the arbitral award (Fouchard and Goldman, 1999). On the main aspects of international arbitration practice, the worldwide consensus is reflected by Model Law being accepted by States across regions and various economic and legal systems. In India, the Arbitration Act 1996 replaced the 1940's Old Arbitration Act with including UNCITRAL Model Law's provisions. As the name suggests, Model Law is only a model. On arbitration, the civil law and the common law are harmonized by the UNCITRAL Model Law. Model Law on International Commercial Arbitration was developed by UNCITRAL to serve as an arbitral procedure's uniform standard.

Harmonizing international trade is an objective of UNCITRAL, and the Model Law forms its integral part, and it is seen as a world of international arbitration's crucial support (Mustill, 1989). Parties that have disputes are benefited by it. It eradicates the frustration caused when national laws of various states demand to be obeyed. For international commercial arbitration, it creates a favourable environment and also serves as a framework. Universality is UNCITRAL's most essential feature (Rubinstein, 2004).

\section{Results and Discussion}

\subsection{Conduct of Procedures__ Different Approaches}

There are different levels where arbitration is regulated, but it is also essential to keep various legal systems, traditions, and cultures. Inevitably, more characterization is provided to international arbitration from the interaction between different legal values and traditions. In the field of international arbitration, the encounter between civil and common law has significant importance (Rubinstein, 2004). However, common and civil law cannot regard as legal rules' two sets, but they possibly represent principles, doctrines, and rules in one or other traditions. For example, significant differences are demonstrated by the civil and common law traditions between each other, while there are also many similarities between them that how can one commence and conduct legal procedures. As far as civil law traditions are concerned, they have been known as a deductive and formal method while applying its statues, common reasoning. While on the other hand, common law traditions are described as an inductive method to judicial discretion to take all particular and relevant facts regarding any case under consideration. 
In contrast, a civil law judge needs to categorize the case while proceeding and making the case fit into a legal tradition or a rule. Such differences between civil and common laws significantly affect the legal proceedings and how they are conducted under any jurisdiction related to each tradition. In their approach these two approaches are way different from each other. They approach dispute settlement and legal proceedings' conduct quite differently (Merryman and Pérez-Perdomo, 2018). The common laws are engaged "search for the truth," whereas the civil law requires the claimant to disclose the facts that would greatly help him in terms of carrying his burden of proof. At very early stages, these differences start appearing in the proceedings. While following this, it is argued that civil and common law traditions establish different requirements regarding the claimant's statement.

For instance, the number of parties involved in the arbitration is shown in figure 2 :

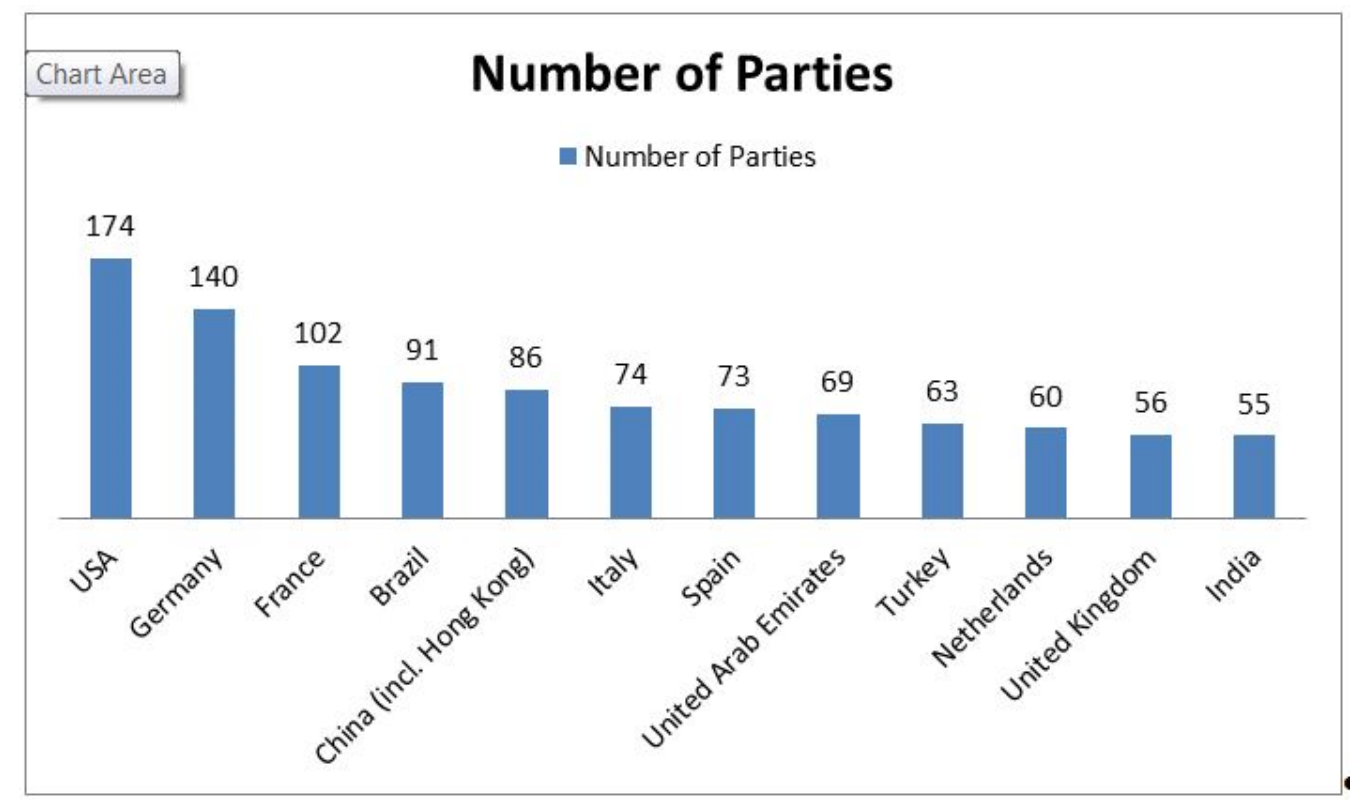

Figure 3. Number of parties (The ICC, 2013)

It is seen that for arbitration seats, Europe had regarded as the favoured destination with London and Paris as one of the leading arbitration centres. While the non-European country, which is famous for it, is Singapore for ICC cases with double cases as Hong Kong. Interestingly, for the first time, Stockholm has also secured its place in the top ten since 2007, as demonstrated in

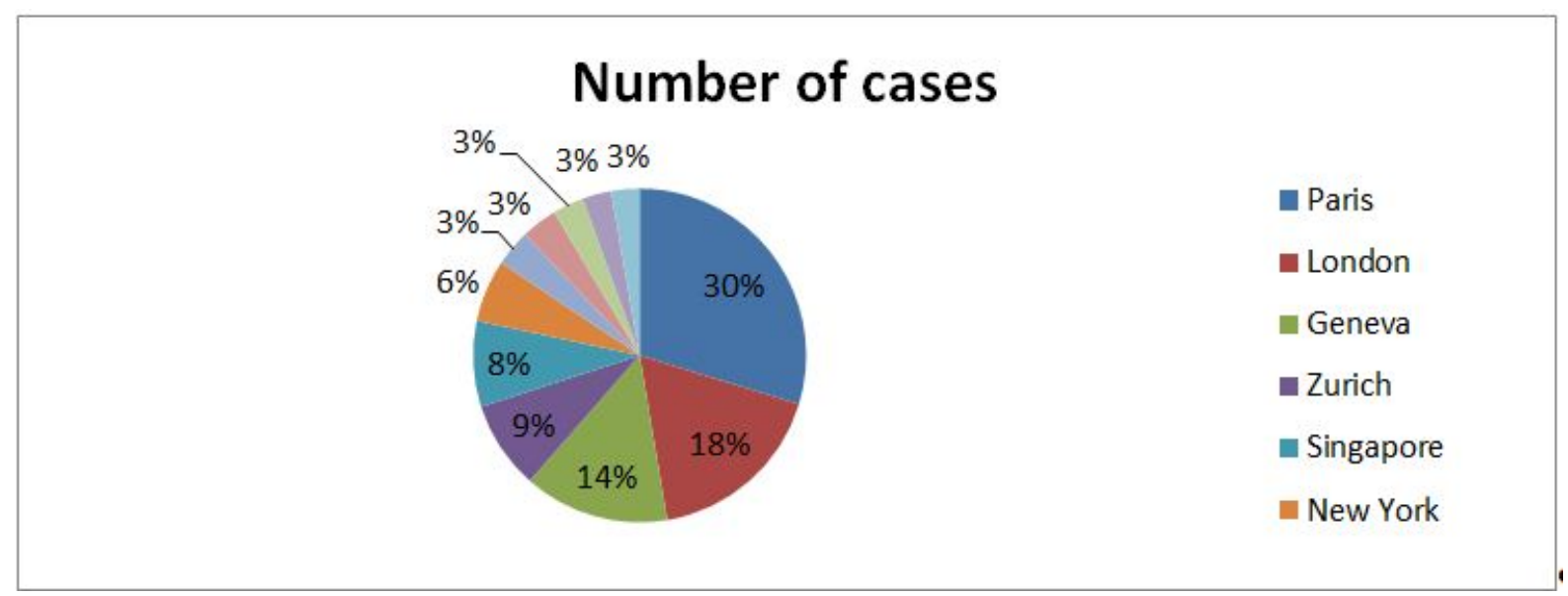

Figure 4. Number of cases (The ICC, 2013)

Any party that initiates any action in the US does not require to formulate its claim precisely while filing the claim. However, its completely different civil law jurisdiction, where any party is taking any action, needs to present a wholly developed statement to fill its claims (Garner, 2009). As far as the gathering of evidence is evidence is 
concerned, there can be found another significant difference between both laws. In common law, discovery is given great importance, while it is not known to civil law jurisdiction. For parties, it is possible to proceed legally in the jurisdiction of civil law to request the court to produce a particular document in possession of a counter-party (Rush, 1994). However, it can be scarcely compared to discovery in the jurisdictions of common law, particularly in the US, where an extreme exercise of finding and dual court system is found. Furthermore, considerable weight is given by common law courts to witness expert evidence as well as testimonies (Rush, 1994).

\subsection{The Amalgamation of Common Law and Civil Law}

In international arbitration, the amalgamation of different legal traditions from both civil and common law has been quite successful. As mentioned earlier, that legitimacy is deprived by arbitration by being allowed in national legislation, but the regulation of arbitration is made at both institutional and international levels (Hobér, 2011). Moreover, according to the party autonomy's principle, the parties have options for selecting any law of their choice. It plays an essential role in helping arbitration an attractive and practical option for commercial contracts. However, a complex picture emerges from this description (Hobér, 2011). International commercial arbitration is regarded as a venue where counsels, arbitrators, and parties from various legal traditions meet. While being dependant on arbitration, more than one law governs the main contract or arbitration process. International codes, conventions, and guidelines relating to international commercial arbitration consist of a mixture of civil and common law traditions (Hobér, 2011). For instance, this is a case with ICC, IBA, and ICA, where all these international organizations are involved in arbitration while basing their codes, conventions, and guidelines on both civil and common law values. The IBA Rules on the proof of pieces of evidence have illustrated this converging consensus.

To a great extent, the rules are described as a compromise between civil and common law approaches to evidence. One respected commentator has noted it, "[t]he different arbitration cultures which exist today are converging more and more, such that it is perhaps even possible to speak of a culture of international commercial arbitration." (Hobér, 2011)He further suggested that "[a] common approach to the conduct of international arbitration is gradually developing." (Hobér, 2011)Such a coherent and detailed system can be considered highly essential for making arbitration a method of dispute settlement across the borders. However, there can be found areas where the common and civil traditions have entirely different international arbitration approaches, causing problems to involved parties in arbitration agreements. A parallel proceeding and approaches to "the doctrine of lis pendens" is an area discrepancy that might be problematic between two legal traditions (Shookman, 2010).

\subsection{Parallel Proceedings and Its Constellations}

Many constellations can be found where a proceeding can be faced by an arbitral tribunal, parallel to ongoing arbitration. When it comes to one of the most typical constellations, it includes parallel proceedings between a national court and an arbitral tribune. For instance, parallel proceeding between a supranational court and an arbitral tribunal or between two arbitral tribunals. In these three scenarios, the first one occurs most commonly. It does not take place more often and brings extra dimensions to the under-discussed issue (Born, 2014). The party that initiates parallel proceedings in national court does not only intend to hamper the proceedings but also try to and crumble the choice of arbitration of any counter-party. Parties need to make an arbitration agreement to foresee which kinds of threats and risks are attached to dispute resolution's choice. A real threat is constituted by parallel proceedings in international arbitration to the parties since it is regarded as a widespread phenomenon (Born, 2014). However, it has been argued that "it might also be in the very interest of at least one of the parties to have its claim tried in multiple jurisdictions." (Born, 2014) There are many motives behind any decision about initiating a parallel proceeding. Some reasons hamper the proceedings, while some play their role in counterbalancing conditions between involved parties by taking advantages and benefits. It has been argued that "when the claimant usually is interested in pushing the proceedings forward to gain the award sought, the respondent rather has an interest in delaying the proceedings. Accordingly, the respondent might initiate a parallel proceeding for that purpose."

Furthermore, a parallel proceeding can be initiated by a party for gaining time to hide assets, which will be subjected to enforcement. Similarly, a party can gain time to erase evidence detrimental and certain transactions to the party. Participating in proceedings can be a costly affair, whether in an arbitral tribunal or a court. Therefore, financial advantage can be taken by a well-off party while initiating a parallel proceeding to put pressure on the rival part to settle the dispute. Likewise, well off parties may purposefully try to keep other parties away from dispute settlement through offensive actions.

\subsection{The Doctrine of Competence-Competence}

In international arbitration, there is a doctrine that needs to be given special attention while dealing with the parallel proceeding, and this doctrine is called the principle of competence-competence. This doctrine constitutes the 
foundation for arbitrators to decide their competence and create spaces to conflict between arbitral tribunals and national courts (Andersson, 2005). In general terms, this doctrine is known as a force in empowering arbitrators to rule their jurisdiction. In other words, the doctrine described in this way that competence is possessed by arbitrators to try their competence, even if they found that they are not competent enough to settle the dispute. Such a tribunal's inherent power comes in the situation where an arbitration agreement's validity or existence is challenged by any of the parties (Andersson, 2005). It helps maintain the arbitration's integrity. If there were no existence of doctrine, the contractual obligation could have been avoided by a party to arbitrate while challenging the tribunal's jurisdiction and claiming that there is no existence of any valid and effective arbitration agreement. It imagined that the complete arbitration system would be undermined by such practice since it would make it an unreliable and ineffective means of dispute resolution (Andersson, 2005). This doctrine is regarded to be international commercial arbitration's general principle, and each national legal system recognizes it. However, there is a unanimous understanding that it exists and provides arbitrators with enough competence in reviewing their jurisdiction. This doctrine works in various jurisdictions with different content (Erk, 2014). There are many jurisdictions, such as Norway and Sweden; the doctrine does not prevent any party from staring proceeding relating the tribunal's competence at any time, not before the decision of the tribunal. That is the doctrine so-called positive notion - the tribunal gives party power to decide its competence, but the international court is not inhibited from ruling on tribunal competence simultaneously. There are countries such as India and France, and negative competence-competence is embraced while prohibiting the national courts to take the jurisdiction of the arbitral tribunal under consideration (Gary, 2014). It waits for the decision of jurisdiction and while giving priority to the arbitral tribunal. Thus, even though there is a consensus about the arbitral tribunal's authorization, there is a disagreement when reviewing the arbitral tribunal's jurisdiction. The approaches differ from each other while keeping in view national legal systems and relations between national courts and arbitral tribunals. The doctrine of separability is linked with the doctrine of competence-competence. In Article 16 (1) of UNCITRAL Model law, both doctrines are codified. According to Article 16 (1), "[t]he arbitral tribunal may rule on its jurisdiction, including any objections to the existence or validity of the arbitration agreement. For that purpose, an arbitration clause which forms part of a contract shall be treated as an agreement independent of the other terms of the contract." As there is a link between two doctrines as if the competence-competence doctrine is derived from its existence from and is dependent upon the separability doctrine (Gary, 2014). However, there has been a completely different view of scholarly writers on such categorization, as they said it is not a correct categorization and suggests that an explanation gives the doctrine's erroneous idea. According to a report, "the competence-competence doctrine comes into play when the existence, validity, or legality of the agreement to arbitrate is challenged and not the main contract between the parties. In these situations, the separability doctrine does not provide much explanation as to how the doctrine of competence-competence empowers the arbitrators to try their jurisdiction." (Gary, 2014) It has been argued that competence-competence doctrine derives its existence from a law that can govern the arbitral tribunal's authority, not from the separability doctrine itself. As competence is provided by competencecompetence doctrine to consider and decide its jurisdiction, it plays an immensely significant role in parallel proceedings' issue, since the competence of not only one but two is entailed to try the arbitral tribunal's jurisdiction (Lew et al., 2003). This doctrine is also a significant source of competence conflicts between national courts and arbitral tribunals while empowering arbitrators to rule their jurisdictions.

\subsection{Difficulties in Parallel Proceedings}

Mostly, inconvenience is caused by two parallel proceedings from at least one point of view of parties. It requires a double amount of work related to ligation, but it is also a costly affair since parties have to attend two different proceedings. It can apply to those cases where there are two parallel proceedings in various jurisdictions that take place. In some cases, these difficulties are the main reason behind initiating a parallel proceeding by a party to an ongoing one. It puts the counterpart in an inferior position, which ultimately leads to a greater inconvenience (Vicuña, 2005). If there is a consensus of a party on arbitration proceeding, a court proceeding is initiated by another party, raising significant concerns for the first one. As the first party has preferred arbitration as the dispute settlement method, it would have probably chosen arbitration after the careful decision. It cannot ignore that the arbitration's advantages are the confidentiality that is followed. From any harm, parties are protected. However, if the other party initiates a parallel proceeding before the national court, there is a danger of losing confidentiality because there is a need to keep arbitration confidential in the same dispute (Vicuña, 2005).

There are many other concerns related to parallel proceedings. The problems are system-related, not party-related. The parties, in arbitration, bear the proceeding's costs. However, the case is different in litigation court, where not only litigate but also the government and taxpayers would pay the cost (Vicuña, 2005). It means that where parallel proceedings occur between a national court and arbitral tribunal, the arbitral tribunal gets turned out to have its 
jurisdiction in the case. Due to this, all the resources used in the court proceedings would waste, and it would be a burden only on parties but society in general. However, it cannot be denied that Parallel proceedings play an essential role in providing a practical perspective. At its worst, parallel proceedings would result in inconsistent or contradictory findings (Erk, 2014).

\subsection{Lis Pendens a Mean to Handle Parallelism}

Before discussing the role of Lis pendens in the civil and common law traditions, it is essential to investigate whether the lis pendens applicable to international arbitration or not. It is vital to distinguish between an arbitral tribunal and a national court and between two arbitral tribunals in the context of Parallelism. (Cuniberti, 2006) It has been established that "a valid arbitration agreement gives the arbitral tribunal exclusive competence to hear the case, eliminating the jurisdiction of the national court." (Cuniberti, 2006) There is a presumption that two competent forums exist, and arbitration agreement plays a vital role in making arbitral tribunal the most superior forum. Despite its "general inapplicability," scholars argue that doctrine has been applied in specific contexts in international arbitration. The most classic example of its applicability in those cases where a party makes a jurisdictional objection challenges the arbitration agreement's validity, applicability, and existence. There is more than one competent forum In these cases for hearing jurisdictional challenges (Cuniberti, 2006).

\subsection{Lis Pendens in the Civil Law Tradition}

The lis pendens doctrine is often described as a civil law tool. Though there is no uniform adoption of this doctrine among jurisdictions of civil law. However, there is a "triple indemnity test" to check whether the Lis pendens doctrine is applicable or not. For this, there is a need for identity between two similar claims; the same parties cannot bring the same case to a second arbitration or litigation. For identification, there is a need of 3 traditional elements by arbitral tribunals and national courts such as

(a) The parties (persona)

(b) The subject matter/ground (causa petendi) and

(c) The object (petitum).

It is widely known as the "triple identity test." However, no unanimous notion can be given with regard to this doctrine and its requirements for identity. But these requirements have been formulated by national legislation somewhat differently. However, the current is not supposed to explore these differences in detail. Furthermore, each element has been interpreted by the CJEU regarding the Lugano Convention. In addition to this, rather strict action has been taken to its application. (Pauwelyn and Salles, 2009)

\subsection{Lis Alibi Pendens in the Common Law Tradition}

In Canada, Britain, New Zealand, Israel, and Australia, lis alibi pendens is not considered a distinct doctrine. It is known as only one of many factors to the adjudicator while applying forum non-conveniens' doctrine. However, forum non-conveniens and lis alibi pendens in the US are viewed as two completely different doctrines. The forum non-conveniens doctrine is applied in the jurisdictions of common law jurisdictions, which confer discretion to decline jurisdiction upon a court where the dispute needs to be tried in another court in the interest of justice. (Pauwelyn and Salles, 2009) Through a large number of English court decisions, this doctrine was established, and the adoption of this doctrine led to a chain reaction among many other jurisdictions of common law, who had been quick in terms of following new English regimes. The Spiliada case can be regarded as one of the typical examples in which Lord Goff describes the doctrine in such a way:

"The basic principle is that a stay will only be granted on the ground of forum non-conveniens where the court is satisfied that there is some other available forum, having jurisdiction, which is the appropriate forum for the trial of the action, i.e., in which the case may be tried more suitably for the interest of all the parties and the ends of justice." (Spiliada case, 1987)

James Fawcett has aptly defined forum non-convenience as "a general discretionary power for a court to decline jurisdiction on the basis that the appropriate forum for trial is abroad or that the local forum is inappropriate." To put it differently, there would be the permission of a stay only if another jurisdiction will play its role as the most appropriate forum. In its assessment, the court would consider whether the plaintiff will be deprived of judicial benefit or not. Moreover, it can be a dispute to be heard in foreign jurisdictions. Several factors will be taken into account by the court to make such determination. An English court might not grant Their proceeding's stay if it is found that the trial will be relatively cheap and quick, damages will be higher, and the English cost rule "the winner takes all" cannot be applied in the international forum. In The case of Abidin Daver, the English court dealt with the case of lis alibi Pendens. A Turkish vessel and a Cuban vessel in March 1982 collided in international water, 
which caused more considerable damage to both. Proceedings were initiated by the Turkish owner against the Cuban owner in Turkey in April 1982. He claimed a significant claiming damage for negligence in the Cuban vessel's management and navigation. A sister ship of Abidin Daver was arrested by the Cuban ship-owners a few months later in England, and the same proceedings were initiated there while highlighting Turkish action. Cuban ship owners claimed that Turkish owners' negligence caused the collision, while Turkish owners did respond while applying to have stayed. (The Vishra Avay case, 1989)

In the Adibin Daver, the main issue was the weight that was to be given to the present situation's existence, where proceedings between same parties on the same subject matter were pending in another forum already such as the lis alibi pendens' existence, in the exercise of discretion the court to stay proceedings. Referring to the previous two cases, it was noted that a lis alibi pendens' situation was not involved by the previous case, whereas the former case - despite the element of Parallelism - did not address lis alibi pendens' issue despite Parallelism's element. (The Vishra Avay case, 1989) Both cases made desirable progress, and it can be described in Lord Diplock's words - from "judicial chauvinism" to "judicial comity." It means two same proceedings between two same parties on the same subject matter in different forums were wholly acknowledged. A test was formulated by Lord Diplock composed for determining whether or not a stay ought to be granted in lis alibi pendens' situation:

"Where a suit about a particular subject-matter between a plaintiff and a defendant is already pending in a foreign Court which is a natural and appropriate forum for the resolution of the dispute between them, and the defendant in the foreign suit seeks to institute as plaintiff an action in England about the same matter then the additional inconvenience and expense which must result from allowing two sets of legal proceedings to be pursued concurrently in two different countries can only be justified if the would-be plaintiff can establish objective by cogent evidence that there is some personal or judicial advantage that would be available to him only in the English action that is of so much importance that it would cause injustice to him to deprive him of it."(Cross and Harris, 1991).

With this, Lord Diplock established lis alibi pendens as a factor of decisive importance in the discretion of the court to stay proceedings, i.e., in applying the doctrine of forum non-convenience. In summary, the applicability of the doctrine of forum non-convenience is not dependent upon the existence of a parallel proceeding pending elsewhere. Instead, the doctrine serves as a ground for the court to decline jurisdiction if it finds that there is some other forum - equally competent - that is more appropriate, regardless if a party has filed a suit in the other forum or not. However, if a parallel proceeding is taking place in a different forum and one of the parties seeks to have the proceedings stayed on this ground, forum non-convenience can be used by the court to decline jurisdiction. In these situations, the lis alibi pendens scenario will be considered in the court's discretion to stay proceedings.

\section{Conclusion}

As mentioned above, parallel proceedings are known as undesirable. As far as the civil law tradition is concerned, lis pendens are regarded as an independent doctrine. It bears the same claim of being tried in various forums simultaneously. In the jurisdiction of common law, lis alibi pendens is not known as a doctrine, but it is viewed as one of many factors applying the forum non-convenience doctrine. However, an exception is posed by the United States to the position, which has been taken by other jurisdictions of common law jurisdictions. Lis alibi pendens is treated in the US as an independent ground to dismiss any case in another forum' (Born and Rutledge, 2018). A homogenous notion of a lis alibi pendens situation's key features from the common law's perspective. All the standards adopted in jurisdictions of common law related to lis alibi pendens are coherent and uniform, irrespective of being treated as a factual circumstance or independent rule to be taken into account in forum non-convenience' application. There can also be seen as another vital difference that emerges during a comparison of civil and common laws (Born and Rutledge, 2018). The court is under an obligation in terms of declining jurisdiction in favour of the first seized court.

To put it differently, No room is left by lis pendens' application for the court's discretion in the matter. On the other hand, empowerment is given to common law courts with discretionary competence while facing lis alibi Pendens. Such discretion is without equivalence (Born and Rutledge, 2018). Additionally, a first-in-time rule is adopted by civil law tradition while applying this doctrine. Within common law, no such rule is found. Put differently, where the second seized of civil law court is supposed to decline jurisdiction, and it happens within a common law court's jurisdiction in terms of deciding whether to do or not. There has been an extensive critique of common law scholars on the civil law approach since they have accused this approach to be too strict and mechanical, which encourages a "race to the courthouses." (Colorado River Water Conservation District case, 1976)

For some reason, a party may find a specific forum specifically beneficial in hearing the dispute. In this case, the first-in-time rule of civil law plays its role in encouraging the party to file its claim in that specific jurisdiction. It 
helps prevent counterparts from initiating a proceeding where the same advantage cannot be achieved. It is also known as the mechanical solution, which can be adopted by either party to have second seized court automatically decline jurisdiction(Born and Rutledge, 2018). Common law scholars have called it an unfair and undesirable act.

On the other hand, in the case of lis alibi pendens, the common law approach plays its role in conferring discretionary power on the court to stay proceedings in this approach, a party is not encouraged to rush to a specific jurisdiction. It is up to the court to determine the most appropriate and effective forum to hear any dispute. However, from a civil law perspective, the predictability's cherished ideal can be challenged by this discretion, as it gets opened up to arbitrary decisions. It can be concluded that a "truth-seeking" element is contained by common law tradition, while the civil law tradition behaves as more deductive and mechanical in its approach (Born and Rutledge, 2018).

It can also be argued that forum non-conveniens doctrine is a more flexible tool as compared to lis pendens doctrine, in terms of conferring discretion on the court and allowing the court to take more factors under consideration along with its evaluation. No or a little room is left by lis pendens for a court to assess anything based on the forums' appropriateness. Furthermore, the parties' indemnity and claims in proceedings can be called the only relevant facts considered by lis pendens.

\section{References}

Andersson, T. (2005). Parallel and Conflicting Enforcement of Law, in Parallel and Conflicting Enforcement of Law. Norstedts Juridik.

August, R. (2004). The Use and Limits of Res Judicata and Lis Pendens as Procedural Tools to Avoid Conflicting Dispute Settlement Outcomes. The Law \& Practice of International Courts and Tribunals, 3(1), 37-77. https://doi.org/10.1163/157180301773732627

Born, G. B. (2014). International Commercial Arbitration: Volume I: International Arbitration Agreements (2nd ed.). Kluwer Law International.

Christian, O. (2014). The Principle of Lis Pendens in International Arbitration: The Swiss Decision in Fomento v. Colon. Arbitration International, 18(2), 137-45. https://doi.org/10.1023/A:1015769930266

Colorado River Water Conservation District v. United States, 424 U.S. 800 (1976).

Cuniberti, G. (2006). Parallel Litigation and Foreign Investment Dispute Settlement. ISCID Review Foreign Investment Law Journal, 21, 1-48. https://doi.org/10.1093/icsidreview/21.2.381

Erk, N. (2014). Parallel Proceedings in International Arbitration: A Comparative European Perspective. Kluwer Law International BV.

Francisco Orrega Vicuña begins his article Lis Pendens Arbitralis with the words "Parallel proceedings, Unwelcome"; see Orrega in Parallel State and Arbitral Proceedings in International Arbitration. (2005). p. 207.

Gaillard, E. (1999). Fouchard-Gaillard-Goldman on International Commercial Arbitration. Kluwer Law International.

Garner, B. A. (2009). Black's Law Dictionary (9th ed.). Thomson Reuters.

George, J. P. (2002). International Parallel Litigation - A Survey of Current Conventions and Model Laws. Texas International Law Journal, 37, 499-540.

Gerhard, W. (2002). Lis Alibi Pendens and Forum Non Conveniens: From Confrontation via Co-Ordination to Collaboration. Eur. JL Reform, 4, 69.

Heuman, L. (2003). Arbitration Law of Sweden: Practice and Procedure. Juris Publishing.

Hobér, K. (2011). International Commercial Arbitration in Sweden. Oxford University Press.

Joost, P., \& Luiz, E. S. (2009). Forum Shopping before International Tribunals:(Real) Concerns, (Im) Possible Solutions. Cornell Int'l LJ, 42, 77.

Lalive, P. (1987). Transnational (or Truly International) Public Policy and International Arbitration, in Comparative Arbitration Practice and Public Policy in Arbitration. In Sanders (Ed.), ICCA Congress Series No. 3. Kluwer Law International.

Lew, J. D. M., Mistelis, L. A., \& Kröll, S. M. (2004). Comparative International Commercial Arbitration. Kluwer Law International. 
Mary, K. (2008). Statutes, Choice of Law, and the Role of Forum Choice. Journal of Private International Law, 4(1), 1-33. https://doi.org/10.1080/17536235.2008.11424331

Merrymand, P.-P. (2007). The Civil Law Tradition: An Introduction to the Legal Systems of Europe and Latin America.

Mustill, M. J. (1989). Arbitration: History and Background. Journal of International Arbitration, 6(2), 43-66.

Paulewyn, S. (2009). Forum Shopping Before International Tribunals: (Real) Concerns (Im)Possible Solutions.

Redfern, A. H. (2009). Martin, Law and Practice of International Commercial Arbitration (5th ed.). Oxford University Press.

Rubinstein, J. H. (2004). International Commercial Arbitration: Reflections at the Crossroads of the Common Law and Civil Law Traditions. Chicago Journal of International Law, 5, 303-310.

Shookman, J. (2010). Too Many Forums for Investment Disputes? ICSID Illustrations of Parallel Proceedings and Analysis. Journal of International Arbitration, 27(4), 361-378.

Spiliada Maritime Corp. v. Cansulex Ltd [1987] A.C. 460.

The Abidin Daver [1984] A.C 398 (at 412, H.L.)

The Vishra Avay case [1989] 2 Lloyd's Rep. 558.

Zweigert, K. K. (2011). Hein, Introduction to Comparative Law (3rd ed.). Oxford University Press.

\section{Copyrights}

Copyright for this article is retained by the author(s), with first publication rights granted to the journal.

This is an open-access article distributed under the terms and conditions of the Creative Commons Attribution license (http://creativecommons.org/licenses/by/4.0/). 